\title{
В. А. Суковатая, Е. Г. Фисун \\ Восток и женственность в работах русских и французских ориенталистов: инверсии взгляда
}

Аннотация: в статье на материале живописи европейского и русского ориентализма ХІХ в. исследуется семантика Востока, которая тесно коррелируется с семантикой женского образа. Авторы стремятся проанализировать эволюцию репрезентаций образа восточной женщины в западноевропейском и русском ориентализме в контексте эволюции диалога Восток - Запад. Новизна работы обусловлена развитием постмодернистской концепции «зрительского взгляда» (gaze) применительно к классической живописи, а также определением особенностей восприятия диалога Восток - Запад в Западной Европе и в России в XIX в.

Ключевъе слова: культурология, женственность, ориентализм, Другой, диалог Восток-Запад, раса, сексуальность, «зрительский взгляд», инверсия взгляда, гендерный анализ.

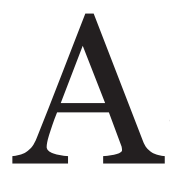
ктуальность данной статьи обусловлена отсутствием философско-антропологического анализа классической живописи XIX в. в контексте взаимосвязей гендера и расы и необходимостью изучения национальных и гендерных различий в восприятии семантики Востока и диалога Восток - Запад. Новизна подхода обусловлена применением постмодернистского и феминистского методологического аппарата к изучению эволюции образов Востока и женственности в живописи европейского и русского ориентализма XIX в. Семантика Востока и женственности в европейском и русском ориентализме анализируется главным образом на материале работ Э. Делакруа, Ж.А. Энгра и В. Верещагина. Методологически работа базируется на идеях постколониализма Э. Саида, Г. Спивак, гендерной теории С. де Бовуар, теории Другого Ж.-П. Сартра, критики власти М. Фуко и А. Грамши, визуальной теории Л. Малви; применяются также структурно-семиотический и сравнительно-описательный методы.

Как известно, концепцию ориентализма в философский обиход ввел Э. Саид ${ }^{1}$ во второй половине $\mathrm{XX}$ в., обозначив тем самым определенный тип отношений между Европой («европейским субъектом») и Другими («неевропейскими объектами»), в число которых входят, по мысли Саида, жители стран Азии, Африки, арабского Востока; представители неевропейской культуры; жители «культурных окраин». Теория Саида в значительной степени базировалась на фукианских идеях критики власти, теории «культурной гегемонии» А. Грамши, концепции Другого, разработанной в теориях гендерной, постколониальной, меньшинств (С. де Бовуар, Ф. Фэнон, Х. Баба), а также «теории взгляда»,

${ }^{1}$ Саид Э. Ориентализм. Западные концепции Востока. СПб. : Русский мир, 2005. впервые сформулированной в трактате Ж.-П. Сартра «Бытие и ничто» и впоследствии получившей развитие в теории визуальных искусств, психоанализе, феминистской философии.

Э. Саид определял ориентализм как систему репрезентаций восточной культуры через призму западного стиля мышления. Одним из важнейших принципов этой репрезентации он считал создание иерархий, в результате которых (европейскому) субъекту явно или скрыто отводилось место культурного и/или политического Центра и «нормативной субъективности», в то время как семантика Востока коррелировалась с идеей «периферии», «маргинальности», «ненормативного тела» (или искаженной «нормы»).

Э. Саид выявил основные причины формирования ориентализма как культурной политики и типа сознания на Западе. По его мнению, это- легитимация стремления Запада властвовать и доминировать над Востоком, закрепленная в оппозициях (Запад - Восток, белый - черный/цветной, христианский - нехристианский, свой - чужой и т. д.); реализация имперских амбиций Запада на этико-эстетическом уровне; акцент на противоречивости, изменчивости, иррациональности восточного Другого, требующего рациональной, логической власти Запада над Востоком. Выводы, которые следуют из ориенталистского типа мышления, имеют, согласно Саиду, политический характер и используются для укрепления «культурного империализма» и символического подтверждения доминирующей позиции Центра (т. е. представителя белой, маскулинной, христианской, гетеросексуальной культуры).

Если обратиться к истории, то интерес Европы к Востоку, введение восточных тем, сюжетов и героев в европейское искусство и литературу стали актуализироваться еще в эпоху географических открытий, начавшихся с путешествий Х. Колумба, 
Культура и искусство 2(14) • 2013

Марко Поло и Афанасия Никитина в эпоху Возрождения. Изображения «мавров» и «турок» широко представлены не только в европейской живописи, но и в литературе того периода (У. Шекспир, М. Сервантес, Ш. Монтескье). Экспедиции Наполеона I Бонапарта в Египет открыла перед западными европейцами, прежде всего французами и англичанами, огромный, чудесный, неизведанный мир, который нельзя было познать европейской логикой и который, с точки зрения европейцев, обладал собственным экзотическим очарованием.

Позже арабский Восток был дополнен колониальной экспансией Франции и Великобритании в африканские и азиатские страны. Таким образом, территориальный образ Востока воспринимался в Европе не столько географически, сколько символически, т. е. как «не-Европа», «не цивилизационная норма». При этом у каждой европейской державы был свой Восток: у французов - преимущественно Ближний Восток, страны Магриба; у англичан одним из главных воплощений Востока долгое время выступала Индия (см. «Индийские рассказы» Р. Киплинга, «Поездка в Индию» Э. М. Форстера). Свой Восток был и у России: среднеазиатские территории, вошедшие в состав Российской империи в XIX в., Кавказ, Дальний Восток и даже внутренние нехристианские народности ${ }^{2}$ как образы российской колонизированной периферии.

Следствием развития «колониального ориентализма» XIX в. явилось, во-первых, стремление проецировать образ «экзотики» на неевропейскую культуру и, во-вторых, стремление Запада узаконить право на управление миром и позиционировать себя в качестве единственно верного варианта развития цивилизации. Исследовательница Э. Каплан ${ }^{3}$ ввела концепцию «имперского взгляда», согласно которой взгляд субъекта, мыслящего «имперскими категориями», упрощает любую культуру, на которую он направлен, так как в соответствии с «порядком имперского мышления» не может допустить, чтобы культурное, религиозное или социальное устройство окраин (провинций) превосходило по сложности или эффективности «имперский центр».

Можно утверждать, что колонизация Востока как части собственной интеллектуальной идентичности Запада происходила путем отчуждения и противопоставления: Восток был превращен в объект наблюдения Запада, в тотального и враждебного Другого, которого Запад стремился не понять, а преобразовывать, поучать, изучать и, тем

\footnotetext{
${ }^{2}$ Соколовский С. Образы Других в российских науке, политике, праве. М.: Путь, 2001.

${ }^{3}$ Kaplan A. Looking for the Other: Feminism, Film, and the Imperial Gaze. Routledge, 1997.
}

самым, закреплять свое право на превосходство. Восток представлял не часть света и не географическое направление, а прежде всего резервуар европейского бессознательного, того наиболее значимого Другого, отношения с которым не могут прерваться никогда.

Женщина, гендер и сексуальность играли и продолжают играть важную роль в концепции ориентализма: если Запад олицетворяют образы «мужчины», «центра», «гегемонии», то Восток логическим образом воспроизводит метафоры «женского», «вторичного», «ненормативного» и «подчиненного», так как именно женщина подчинена мужчине в традиционной иерархии европейских ценностей. В своей концепции ориентализма как типа культурной, расовой и сексуальной доминации Запада (Европы) над Востоком (неевропейскими окраинами) Э. Саид творчески развил идеи А. Грамши 4 о классовой и гендерной гегемонии и теорию Ж. П. Сартра 5 о зависимости между взглядом и властью. Именно взгляд (spectator's look), возможность наблюдения субъекта (активного) превращает того, за кем наблюдают, в Другого в пассивный, зависимый объект изучения или отчуждения. Даже зритель (кино или произведений живописи), рассматривая малейшие (интимные) детали картин, утверждает свою символическую власть над данным отрезком чужой повседневности, времени и пространства.

Концепция взгляда (gaze) была развита феминистскими исследовательницами Л. Малви, А. Каплан и Ж. Росс на материале кино и популярной культуры. В частности, в знаменитом эссе «Визуальное удовольствие и нарративный кинематограф» (1975) Малви ${ }^{6}$ исследовала принципы гендерной асимметрии, осуществляемой в кино дважды: камерой, репрезентирующий «патриархатный взгляд» мужчины-наблюдателя, и зрителем-мужчиной, получающим удовольствие от наблюдения за Другим, т. е. женщиной. Малви утверждала, что именно обладание способностью наблюдать, следить за кем-то, оставаясь невидимым для объекта наблюдения, т. е. объективировать Другого, указывает на «мужской» статус в культуре, на того, кто обладает властью. Согласно теории взгляда, мужчина проецирует свои эротические фантазии на экран и объективирует их в образах, в то время как женщина-зритель ощущает себя объектом эротического слежения, лишенным собственной

\footnotetext{
${ }^{4}$ Грамши А. Избранные произведения: В 3 т. Т. 3: Тюремные тетради. М.: Иностранная литература, 1959.

${ }_{5}^{5}$ Сартр Ж. П. Бытие и ничто: Опыт феноменологической онтологии. М.: Республика, 2004 .

${ }^{6}$ Малви Л. Визуальное удовольствие и нарративный кинематограф // Антология гендерной теории. Минск: Пропилеи, 200о. С. 280-297.
} 


\section{Этнология и культурная антропология}

субъективности. Таким образом, традиционное кино построено как репрезентация «мужского» удовольствия наблюдения за Другим, когда Другим как правило выступает женщина.

Интерпретируя идеи Малви, Каплан и Саида, можно заметить, что именно обладание способностью наблюдать, оценивать, критиковать отличает традиционно мужской статус от женского, чья позиция состоит в том, что женщина как бы подставляет себя «мужскому» («зрительскому») взгляду, открывает себя, демонстрирует, старается понравиться. Даже в тех случаях, когда женщина пытается скрыться от взгляда наблюдающего субъекта, она, тем не менее, принимает этот взгляд самим фактом изменения своего поведения. С точки зрения властных отношений, взгляд становится символом контроля и установления иерархий; в кино - это взгляд зрителя на экран, в живописи - взгляд художника и зрителя на объект изображения. Таким образом, можно заключить, что изображение восточной женщины на полотнах европейских ориенталистов становилось пространством пересечения нескольких иерархических оппозиций: Запад - Восток как центр - периферия, мужское - женское как доминирующее - подчиненное. Женское тело, лежащее на пересечении места (Востока), расы и гендера, являлось идеальным резервуаром для сексуально-властных воплощений мужчины.

Попробуем проанализировать, применимы ли концепции анализа кино, разработанные Малви и Каплан, к анализу живописи XIX в.

Образы восточных женщин были не редки в европейской живописи, начиная с эпохи Возрождения. Первые изображения восточных женщин в искусстве эпохи Возрождения были связаны главным образом с библейскими темами или образами Ветхого Завета. Однако можно утверждать, что популярность неевропейских женщин в европейском искусстве была обусловлена не столько модой эстетических концепций (академизм, романтизм, импрессионизм), сколько политическими реалиями и общественным мнением о статусе неевропейской женщины в иерархии европейского общества. В частности, британский искусствовед Дж. Бергер 7 считает, что в эпоху Возрождения и барокко фигуры обнаженных женщин были написаны почти исключительно для мужского зрителя: женщин часто изображали повернутыми обнаженным телом к зрителю, в то время как их лица часто отвернуты к зеркалу или недоступны зрительскому взгляду. С нашей точки зрения, подтверждение идей Бергера легко обнаружить в живописи великих фламандцев: например, в известной картине

${ }^{7}$ Berger $J$. Ways of Seeing. Penguin Group, 1972.
П. П. Рубенса и Я. Брейгеля «Возвращение с войны: Марс, разоруженный Венерой» (1610-1612), где в образе античных богов представлена бытовая сценка встречи любовников, а центром картины выступает пышная обнаженная фигура дородной белокожей женщины в недвусмысленной сексуальной позе. В этой картине зритель явно ощущает себя случайным вуайеристом, как, впрочем, и в ряде других известных картин: «Марс и Венера объединенные любовью» Веронезе (1570), «Даная» Тициана (1564), ряд полотен Брейгеля и Рубенса. В большинстве случаев изображенные на них женщины заняты любовной игрой, и зритель-мужчина может получать наслаждение от подглядывания за эротическими сценами, как бы находясь в естественных условиях уличного, повседневного подглядывания.

Однако европейская гендерная мораль со времен Возрождения и до XIX в. существенно менялась, становясь более консервативной: в рамках буржуазной морали XIX в. изображение обнаженной женской натуры было возможно, только если сюжет имел отсылку к временам античности (как, например, «Рождение Венеры» А. Кабанеля, 1863) или к пространствам сказочным, экзотическим, удаленным от Европы (как, например, таитянский цикл П. Гогена, в котором обнаженными натурщицами представлены женщины небелой расы, с неевропейскими пропорциями лица и фигуры (например, «Портрет яванки Аннах», 1894). Именно скрытые общественные потребности в изображении обнаженного женского тела, доставлявшего вуайеристское наслаждение как мужчинам-художникам, так и мужчинам-зрителям, было дополнительным стимулом обращения к Востоку, как тому неевропейскому пространству-времени, которое искушало европейскую культуру своими неисчерпаемыми возможностями наслаждения, запрещенными нормами приличия в европейском обществе XIX в. Восточный гарем становится одним из излюбленных пространств европейской живописи, способом указать на специфику бытия расово-гендерного и сексуального Другого ${ }^{8}$. На картинах Ж. Д. Энгра, Э. Делакруа, Э. Фромантена, Т. Шоссерио, П. Делароша изображены сливочнотомные, почти обнаженные тела восточных красавиц, мучениц и одалисок, нагота которых открыта взгляду европейского зрителя. Назовем для примера несколько картин: Э. Делакруа «Женщина с попугаем» (1827); У. Этти «Кандавл, царь Лидии показывает украдкой свою жену, ложащуюся в кровать, своему министру Гигес» (1820); П. Деларош «Девушка у бассейна» (1845); Т. Шоссе-

${ }^{8}$ Суковатая В. А. Лицо Другого: телесные образы Другого в культурной антропологии. Харьков: ХНУ, 2009. С. 201-202. 
Культура и искусство 2(14) • 2013

рио «Эсфирь наряжается для встречи с королем» (1842). Тело восточной красавицы, которое можно выставлять напоказ и которое неподвластно запретам христианской морали, становится центром внимания в ориенталистской живописи.

Легко заметить, что визуальной особенностью большинства ориенталистских сюжетов европейских художников XIX в. выступает очевидное акцентирование экзотичности Востока, что означало стремление художников создавать произведения с позиции дистанцирования себя (как европейского субъекта) от инородной (восточной) ментальности. Как следует из дневников и личных писем ${ }^{9}$, чаще всего изображение Востока не предполагало деконструкции устоявшихся европейских стереотипов о «центре - периферии», «женственности- мужественности»; Восток привлекал художников прежде всего в качестве материала для популяризации западных цивилизационных идеалов, что придало особый характер и способам воплощения восточной женщины в ориенталистской живописи.

Наша концепция заключается в следующем: ориентализм на протяжении XIX в. не был монолитным, в самой ориенталистской парадигме можно найти элементы деконструкции ориенталистской идеологии; существует разница национальных «ориентализмов» (в частности, французского и русского), которая отображена в разнице сюжетов и тем; направленность «зрительского взгляда» эволюционировала в ориенталистской живописи XIX в. вследствие эволюции представлений о диалоге «Восток -Запад» в сознании того времени.

На наш взгляд, анализ двух наиболее репрезентативных картин французского ориентализма очевидным образом продемонстрирует эволюцию европейского взгляда на Восток и тип восточной женственности. В классической работе Ж.О. Д. Энгра «Одалиска с рабами» (1839) главная задача автора, мэтра академизма, состояла в усовершенствовании пластических форм, визуальной четкости пропорций тела в соответствии с идеологией академизма. На этой картине изображена лежащая в расслабленной позе обнаженная женщина с распущенными волосами, лишь лоно ее прикрыто полупрозрачной простыней. Ее окружают темнокожие рабы, играющие на восточных музыкальных инструментах. Ориенталистское мышление Энгра проявилось в характере обнажения героини картины: она обнажена настолько, насколько художник никогда бы не посмел обнажить на картине белую француженку; однако с «чужой» (восточной) женщиной можно проделывать то, чего нельзя со «своей» (европейской) даже на картине. Поэтому мож-

9 Делакруа Э. Дневник Делакруа. М. : Искусство, 1950; Жюллиан Ф. Эжен Делакруа. М.: Искусство, 1986. но утверждать, что в картине Энгра имплицитно присутствует оппозиция «своего» (западного) как пристойного, морального, нормативного) и визуализированного «чужого» (восточного) как непристойного, развратного, нарушающего гендерные нормы стыдливости.

Спустя 18 лет в картине романтика Э. Делакруа «Одалиска» (1857) образ восточной женщины уже представлен менее схематично: восточная красавица изображена как объект экзотической телесности и как социально детерминированный, но духовно раскрепощенный субъект. На картине Делакруа мы видим темноволосую женщину с богатым телом, сидящую прямо перед зрителем, и глядящую с полуулыбкой в упор, как бы осознающую свою власть над зрителем-мужчиной. Л. Вервари, выделяя художественные особенности «Одалиски» Делакруа, писал, что образ восточной женщины стал для художника типом, в котором одухотворяется эротика ${ }^{10}$. Можно утверждать, что для Делакруа тело восточной женщины интересно не в качестве предмета идеализированных внешних форм (которые стремился смоделировать Ж. О. Д. Энгр), но как самобытный тип (восточной) женственности, недоступный в полной мере европейской телесности.

Более того, выявляется и определенное смещение «взгляда наблюдателя» $\left(\right.$ gaze $\left.^{11}\right)$, в результате которого зрителю (spectator's look) становятся доступны разные локусы восточного мира. Если позицию зрителя в картине Энгра «Одалиска с рабами» можно идентифицировать как позицию европейца-соглядатая, того, кто случайно и скрытно (втихаря) проник на женскую половину восточного дома и подглядывает в щелку картинки из жизни гарема - наиболее экзотического и непонятного феномена восточной сексуальности, то «Одалиска» Э. Делакруа, на наш взгляд, изображает восточную женщину в фокусе взгляда восточного мужчины. Что указывает на это?

Если героиня Энгра в «Одалиске с рабами» обнажена соблазнительно и непристойно, нагота ее тела акцентирована, а лицо имперсонально в полуобороте, то в «Одалиске» Делакруа героиня не скрывает своего лица, ее взгляд устремлен на зрителя, как бы приглашая к известной и приятной обоим игре, а тело размыто и не прорисовано четкими линиями, давая только намек на женскую наготу. Восточность «Одалиски» Энгра подчеркивают внешний антураж, экзотичное окружение, в то время как в «Одалиске» Делакруа восточные

\footnotetext{
${ }^{10}$ Вергвари Л. Делакруа. Будапешт: Из-во Корвина, 1963. ${ }^{11}$ Rose G. Visual Methodologies: An Introduction to Researching with Visual Materials. AGE Publications Ltd; Third Edition, 2011.
} 


\section{Этнология и культурная антропология}

признаки не акцентированы ничем, кроме названия и декоративного одеяния. Можно сказать, что одалиска на картине Делакруа ничем не отличается от парижской любовницы, ждущей возлюбленного. Иначе говоря, если демонстрация Востока и женственности на картине Энгра сконструирована как бы с позиции «чужого» мужчины-зрителя, для которого самым заманчивым является экзотизм чужой культуры и сексуальности, то на картине Делакруа героиня изображена в фокусе взгляда близкого ей, «своего» (восточного) мужчины, для которого главным привлекательным моментом является не экзотизм Другого, а искренняя, открытая, игривая сексуальность женщины.

Особенности гендерной субъективности в картине Э. Делакруа заключаются в том, что для восточного человека его «Одалиска» не переходит границы морали, в то время как европеец стремится насладиться процессом созерцания «запрещенной наготы». На наш взгляд, в этой картине восточная женщина воплощает европейские представления о женской сексуальности, декорированные под восточный экзотизм: восточная женщина в европейском бессознательном ориентализма это вариант сексуально доступной (европейской) женщины, чья доступность разумеется сама собой, так как это доступность «колонизированного объекта» взгляду и власти «колонизатора».

Если обратиться к концепции Другого у Ж.-П. Сартра ${ }^{12}$, то следует вспомнить, что по Сартру процесс взаимопроникновения субъекта в сущность «другого» может реализовываться только через проецирование личностных характеристик на «другое тело», которые для созерцающего изначально являются орудием самопознания, что всегда приводит к деформации образа «теладля-другого». В контексте теории Сартра можно утверждать, что Энгр и Делакруа конструируют тело одалиски как «тела-для-другого», себе подобного европейца, в представлении которого восточная женщина функционирует в качестве «украшения», отличающегося особой экзотичностью. Если обобщить позиции французских ориенталистов, то очевидно, что оба маскулинизируют и европеизируют зрительский взгляд, как бы навязывая Востоку европейские представления об удовольствии от рассматривания женского тела.

Иной тип зрительского взгляда мы идентифицируем в картине В. Верещагина «Узбекская женщина в Ташкенте» (1873), который наряду с Ж. О. Д. Энгром и Э. Делакруа продолжает тему «восточной женственности». На полотне

\footnotetext{
${ }^{12}$ Сартр Ж. П. Бытие и ничто: Опыт феноменологической онтологии. М.: Республика, 2004 .
}

Верещагина изображена азиатская женщина в закрытой мусульманской одежде, даже лица которой увидеть невозможно. В отличие от французских ориенталистов русский художник строго придерживается принципов реализма в передаче восточного быта и образа жизни восточной женщины. Его работа принципиально сфокусирована на изображении патриархального уклада и неромантичной гендерной повседневности, в рамках которой восточная женщина выступает как повод поразмышлять о судьбе (а не о теле) Другого. Верещагин помещает фигуру узбекской женщины в ее бытовое пространство, где женщина может репрезентировать себя только в рамках собственной семьи. Ее подчиненное положение подчеркивают покорная поза и полное отсутствие лица, глаз, скрытых паранджой, которую разрешается снимать только мужу или хозяину.

Такая сокрытость может быть истолкована двояко: как обезличивание женщины восточной культурой, но и как загадочность, непредсказуемость как самой женщины, так и культуры, все эмоции и желания которой остаются невидимыми для внешнего наблюдателя-европейца. Можно утверждать, что зрительский взгляд в картине В. Верещагина сконструирован с позиции европейца, однако европейца, с уважением относящегося к ценностям восточной культуры и не нарушающего их. Как известно, в мусульманской культуре существуют три уровня доступности тела восточной женщины, основывающихся на принадлежности мужчины к определенной этнокультурной группе: «своим» мусульманская женщина считает только мужа, и только для него она может быть обнажена; остальные мужчины мусульманского мира занимают «маргинальное» положение, а европеец выступает «чужим» и потому субъективность и сексуальность восточной женщины скрыты от него. Таким образом, изображая восточную женщину в полностью скрывающей тело и лицо парандже, Верещагин тем самым демонстрирует открытость к диалогу Восток - Запад и принятие иных культурных традиций, переступать которые он не намерен.

В дискуссиях о «восточной женственности» в живописи XIX в. можно усмотреть желание французских ориенталистов репрезентировать модель женщины с позиций взгляда европейского мужчины, в то время как Верещагин, представитель русского ориентализма, обращается к сюжетам, косвенным образом предполагающим признание позиции культурного Другого как полноправного участника диалога. На наш взгляд, это обусловлено демократическими взглядами самого 
Культура и искусство 2(14) • 2013

художника, а также спецификой русского ориентализма, в значительной степени впитавшего пафос русской демократической литературы XIX в. (вспомним Н. Гоголя, Ф. Достоевского, Н. Лескова) и ориентированного на обличение и осуждение социальных проблем и колониализма. Автор «Туркестанской серии» и знаменитого полотна «Апофеоз войны» (1871) уже в ранний период своего творчества был страстным противником войны, жестокости по отношению к мусульманскому населению. Можно утверждать, что восточная женщина на его картинах изображена в ее обыденной обстановке, с сохранением типических взаимосвязей, что позволяет ее субъективности проявиться в более естественной форме.

Если выстраивать эволюцию европейского ориентализма в хронологическом порядке (от Энгра к Делакруа и к Верещагину), то можно идентифицировать значительную трансформацию в идеологии ориентализма на протяжении XIX в.: от копирования внешних форм восточного экзотизма и чужеродной повседневности к передаче всеобъемлющего опыта восточной жизни, отличного от европейского. Такое изменение стало возможным в результате расширения диалога Восток - Запад и восприятия восточной субъективности не как «чужой», но как амбивалентной, «открытой», Другой, которую не следует отвергать. В литературе это новое (сочувственное) отношение к расовому и этническому Другому ярко проявилось в произведениях французов В. Гюго («Собор Парижской Богоматери») и Ж. Верна («Паровой дом» и др.), а также в «Хаджи-Мурате» и «Кавказском пленнике» Л. Н. Толстого.

Однако немалую роль играют и особенности национальных традиций общения с культурными Другими, и субъективный опыт и мировоззрение художника. Тематический диапазон ориентализма показан нами на примере картин Ж. О. Д. Энгра, Э. Делакруа и В. Верещагина, где женские образы эволюционировали «от непристойности к повседневности». Зритель же интерпретировал тело восточной женщины в зависимости от личного мировосприятия, конфессиональной принадлежности, моральных норм, социального положения. Изменение зрительского взгляда можно представить как в виде хронологической эволюции, так и в инверсивном порядке: если принять в качестве исходной точки взгляда субъективность «восточного мужчины», то для него «Узбекская женщина» В. Верещагина отразит привычную гендерную повседневность, «Одалиска» Э. Делакруа шокирует чрезмерным обнажением тела, не принятым в ситуации общения восточной женщины с представителями другой культуры (а потому неправдоподобным), а работа Ж. О. Д. Энгра подглядыванием за телом чужой женщины способна вызвать эмоции неприятия (возмущения).

Кажется очевидным, что работы французских ориенталистов нацелены на пробуждение у европейского мужчины эротических инстинктов (подобно тому, как на наших современников воздействуют иллюстрации из эротических журналов, на страницах которых женское оголенное тело удерживает «мужской взгляд»). Для Ж. О. Д. Энгра и Э. Делакруа помещение обнаженной женщины в центр их картин было важным шагом в эротическом раскрепощении современного им французского общества. Однако ни в начале, ни в середине XIX в. французские художники не могли сделать героинями своих произведений обнаженных француженок (вспомним, каким скандалом сопровождалось появление знаменитого полотна Э. Мане «Завтрак на траве» в Парижском салоне 1863 г.!). Как известно, возмущение зрителей вызвало не только полное обнажение женщин на картине (при полностью одетых мужчинах), но и то, что персонажи картины были французами и француженками, хорошо известными парижанам тех лет. Изображение обнаженного женского тела восточной, а не европейской, красавицы автоматически снимало обвинения в безнравственности (ведь с женщинами «чужих» наций дозволено то, что не дозволено со «своими»). Пространство женщины, утверждают теоретики постколониализма ${ }^{13}$, воплощает дискурс нации, именно через противопоставление тела женщины собственной нации как «дома» («матери», «жены») телу «чужих», обнажаемых женщин (как представительниц сексуально-расового тела колоний) происходит конструирование доминирующего маскулинного имперского Субъекта и колонизируемого феминного Другого.

Подводя итог, следует сказать, что в европейской живописи XIX в. в открытии новых тем и сюжетов отразились социокультурные политики (т. е. политические идеологемы в бартовском значении термина' ${ }^{14}$ д диалога Восток - Запад, прежде всего связанные с национальными (французскими, английскими, русскими) представлениями о том, что есть Восток. Тематический комплекс ориентализма был дополнен новыми способами художественной изобразительности, такими как: использование яркой палитры, наличие восточ-

\footnotetext{
${ }^{13}$ Mohanram R. Black body. Woman, Colonialism and Space. University of Minnesota Press, Minneapolis, London, 1999.

${ }^{14}$ Барт Р. Мифологии / Пер. с франц. М.: Директ-Медиа, 2007. $459 \mathrm{c}$.
} 


\section{Этнология и культурная антропология}

ной стилизации, новое понимание телесной пластики. Однако главным было появление новых тем и визуальные утверждения колониальной идеологии в части ориенталистской живописи. Часто «восточное тело» было построено как «ненормативное тело» - по сравнению с «европейскими нормами» поведения женщины и жизненного пространства (например, в картинах Энгра). Именно поэтому гарем являлся излюбленным местом изображения восточных женщин в живописи ориенталистов - европейцев.

Поскольку в европейской культуре Восток понимался как периферия цивилизации, то и женское тело и образы «восточной сексуальности» выступали символами экзотического и странного Востока. По этой причине образы восточных женщин в европейской живописи были смоделированы как часть «колониального воображения» европейского общества и отражали не реальную жизнь восточной женщины, но понятия, предубеждения, культурные концепции европейского общества о Востоке, о европейской культурной гегемонии, о восточной женственности. Они имели существенное значение для понимания развития европейской субъективности XIX в. (как, например, в живописи Делакруа).

Вместе с тем в рамках самой концепции ориентализма обнаруживаются элементы ее деконструкции, прежде всего в творчестве В. Верещагина, что свидетельствует о национальных особенностях ориенталистской идеологии, отраженной в живописи. Французские ориенталисты Ж. О. Д. Энгр и Э. Делакруа разрешают проблему диалога Восток Запад в пользу европейской идеологии: обнажают восточную женщину, представляют ее в роли военного трофея, украшения, тем самым осуществляя над ней «двойную» или «повторную» колонизацию. Русский ориентализм в лице Верещагина отличается от французского целенаправленным воспроизведением социальных и политических проблем на Востоке в XIX в.

Противостояние Запада и Востока, рационализированное западным мышлением с приданием образам экзотических культур характера «дикости» и «варварства», получает у живописцев развитие в разных вариантах: В. Верещагин ставит на первое место проблему равноправного диалога между двумя цивилизациями, а Э. Делакруа применяет известные сюжеты из исторического прошлого для решения вопросов своего поколения. Отталкиваясь от анализа полотен Ж. О. Д. Энгра, Э. Делакруа и В. Верещагина, можно сказать, что процесс эволюции ориентализма как тенденции в изобразительном искусстве XIX в. не ограничивается рамками одной интерпретации. Характер аргументации той или иной точки зрения, оценка типа эволюции ориентализма во многом будет зависеть от того, к какому типу идентичности (гегемонному или колониальному) относит себя воспринимающий субъект.

\section{Список литературы:}

1. Барт Р. Мифологии / Пер. с франц. М.: Директ-Медиа, 2007. 459 с.

2. Вергвари Л. Делакруа. Будапешт: Из-во Корвина, 1963.

3. $\quad$ Грамши А. Избранные произведения: В 3 т. Т. 3: Тюремные тетради. М.: Иностранная литература, 1959.

4. Делакруа Э. Дневник Делакруа. М.: Искусство, 1950

5. Ж Жллиан Ф. Эжен Делакруа. М.: Искусство, 1986.

6. Малви Л. Визуальное удовольствие и нарративный кинематограф // Антология гендерной теории. Минск: Пропилеи, 200о. С. 280-297.

7. Саид Э. Ориентализм. Западные концепции Востока. СПб.: Русский мир, 2005.

8. Сартр Ж. П. Бытие и ничто: Опыт феноменологической онтологии. М.: Республика, 2004 .

9. Соколовский С. Образы Других в российских науке, политике, праве. М.: Путь, 2001.

10. Суковатая В. А. Лицо Другого: телесные образы Другого в культурной антропологии. Харьков: ХНУ, 2009.

11. Berger J. Ways of Seeing. Penguin Group, 1972.

12. Kaplan A. Looking for the Other: Feminism, Film, and the Imperial Gaze. Routledge, 1997.

13. Mohanram R. Black body. Woman, Colonialism and Space. University of Minnesota Press, Minneapolis, London, 1999.

14. Rose G. Visual Methodologies: An Introduction to Researching with Visual Materials. AGE Publications Ltd; Third Edition, 2011.

\section{References (transliteration):}

1. $\quad$ Bart R. Mifologii. Moskva: Direct-Media, 2007.

2. Vergvari L. Delakrua. Budapesht: Iz-vo Korvina, 1963. 


\section{Культура и искусство 2(14) • 2013}

3. Gramshi A. Izbrannye proizvedeniya: V 3 t. T. 3: Tyuremnye tetradi. M.: Inostrannaya literatura, 1959.

4. Delakrua E. Dnevnik Delakrua. M.: Iskusstvo, 1950.

5. Zhyullian F. Ezhen Delakrua. M.: Iskusstvo, 1986.

6. Malvi L. Vizual'noe udovol'stvie i narrativnyy kinematograf // Antologiya gendernoy teorii. Minsk: Propilei, 2000. S. $280-297$.

7. Said E. Orientalizm. Zapadnye kontseptsii Vostoka. SPb.: Russkiy mir, 2005.

8. Sartr Zh. P. Bytie i nichto: Opyt fenomenologicheskoy ontologii. M.: Respublika, 2004.

9. $\quad$ Sokolovskiy S. Obrazy Drugikh v rossiyskikh nauke, politike, prave. M.: Put', 2001.

10. Sukovataya V. A. Litso Drugogo: telesnye obrazy Drugogo v kul'turnoy antropologii. Khar'kov: KhNU, 2009.

11. Berger J. Ways of Seeing. Penguin Group, 1972.

12. Kaplan A. Looking for the Other: Feminism, Film, and the Imperial Gaze. Routledge, 1997.

13. Mohanram R. Black body. Woman, Colonialism and Space. University of Minnesota Press, Minneapolis, London, 1999.

14. Rose G. Visual Methodologies: An Introduction to Researching with Visual Materials. AGE Publications Ltd; Third Edition, 2011. 